\title{
RELATIONSHIP BETWEEN THE PRESENCE OF HELICOBACTER PYLORI WITH INFLAMMATORY ENDOSCOPIC CHANGES IN GASTRODUODENAL MUCOSA
}

\author{
Relação entre a presença do Helicobacter pylori com alterações endoscópicas inflamatórias na mucosa gastroduodenal \\ Irma Cláudia Saboya RIBEIRO',2, Luiz Fernandao KUBRUSLY'1, Paulo Afonso Nunes NASSIF', \\ Patrícia Fernanda Saboya RIBEIRO'ㄹ, Rodrigo de Oliveira VERAS ${ }^{1}$, Aline NEPPEL ${ }^{1}$
}

From the ${ }^{1}$ Programa de Pós-Graduação em Princípios da Cirurgia, Faculdade Evangélica do Paraná/Hospital Universitário Evangélico de Curitiba/Instituto de Pesquisas Médicas; and ${ }^{2}$ Serviço de Endoscopia Digestiva, Centro de Diagnóstico e Terapêutica Endoscópica de São Paulo, Hospital 9 de Julho, São Paulo, SP, (Postgraduate Program in Principles of Surgery, Evangelic Faculty of Paraná/ University Evangelic Hospital of Curitiba/ Medical Research Institute, Curitiba, PR; and ${ }^{2}$ Gastrointestinal Endoscopy Service, 9 of July Hospital, São Paulo, SP), Brazil

HEADINGS - Endoscopy. Esophagitis. Gastrites. Duodenitis. Helicobacter pylori. Inflammation.
ABSTRACT - Background: The influence of Helicobacter pylori (HP) in inflammatory disorders of the digestive mucosa has been the subject of several studies since socioeconomic, personal and environmental factors were implicated in the bacteria transmission. Aim: To correlate the inflammatory endoscopic findings with HP infection and the onset of mucosal diseases mucous of the upper digestive tract. Method: Comparative observational study, in which were collected data from 2247 patients who underwent upper endoscopy and biopsies for HP with urease test. The patients were divided into two groups: HP+ and HP- (control) in which endoscopic findings were observed for the following changes: esophagitis, esophageal ulcer, gastritis, erosive gastritis, gastric ulcer, bulboduodenitis, bulbar ulcer and without disease. Results: As for esophagitis, there was little disparity in the distribution favorable to HP+ group $(\mathrm{HP}+=67.11 \%$ and $\mathrm{HP}-=69.89 \%)$ and esophageal ulcer (HP+ $=0 \%$ and HP- $=0,21 \%)$. Gastritis was favorable to HP- group ( $\mathrm{HP}+=78.34 \%$ and $\mathrm{HP}-=73.63 \%$ ), as well as erosive gastritis ( $\mathrm{HP}+$ $=67,11 \%$ and $\mathrm{HP}-=64,55 \%)$, in bulboduodenitis ( $\mathrm{HP}+=1,87 \%$ and $\mathrm{HP}-1,23 \%)$, in gastric ulcer $(\mathrm{HP}+=2,14 \%$ and $\mathrm{HP}-=2,03 \%)$ and in the absence of alterations in the HP+ group (4.81\%) with the HP- control group (6,30\%), in which there was little disproportion in favor of HP-group, but without statistical significance. As for the bulbar ulcer (HP $+=10.16 \%$ and HP- $=4.48 \%$ ), there was statistically significant $(p=0.00001)$. Conclusion: There is no difference between HP+ and HP- groups in inflammatory changes in endoscopic gastroduodenal mucosa, except for the relationship between HP and bulbar ulcer.

\section{Correspondence:}

Irma Saboya

E-mail: irmagrau592@gmail.com

Financial source: none

Conflicts of interest: none

Received for publication: 29/01/2016 Accepted for publication: 14/04/2016

DESCRITORES - Endoscopia. Esofagite. Gastrite. Duodenite. Helicobacter pylori. Inflamação.
RESUMO - Racional: A influência do Helicobacter pylori (HP) nas alterações inflamatórias das mucosas digestivas tem sido objeto de vários estudos uma vez que fatores socioeconômicos, pessoais e ambientais são implicados na transmissão da bactéria, facilitando-a. Objetivo: Relacionar os achados inflamatórios endoscópicos com a infecção pelo HP e o aparecimento de doenças mucosas do trato digestivo alto. Método: Estudo observacional comparativo, o qual foram coletados dados de 2247 pacientes submetidos à endoscopia digestiva alta e biópsias para HP com teste de urease. Os pacientes foram divididos em dois grupos: HP+ e o controle HP-dentro dos quais foram observados os achados endoscópicos referentes às seguintes alterações: esofagite, úlcera esofágica, gastrite, gastrite erosiva, úlcera gástrica, bulboduodenite, úlcera bulbar e sem doença. Resultados: Quanto à esofagite, observouse pequena desproporção na distribuição, favorável ao grupo $\mathrm{HP}+(\mathrm{HP}+=67,11 \%$ e HP$=69,89 \%)$ bem como na úlcera esofágica (HP+ $=0 \%$ e HP- $=0,21 \%)$. Na gastrite foi favorável ao grupo $\mathrm{HP}$ - $(\mathrm{HP}+=78.34 \%$ e $\mathrm{HP}-=73.63 \%)$, assim como na gastrite erosiva $(\mathrm{HP}+=67,11 \%$ e HP- $=64,55 \%)$, na bulboduodenite ( $\mathrm{HP}+=1,87 \%$ e HP- $1,23 \%$ ), na úlcera gástrica (HP+ $=2,14 \%$ e HP- $=2,03 \%)$ e na ausência de alterações no grupo HP+ $(4.81 \%)$ com o grupo controle HP- (6,30\%), nos quais há pequena desproporção favorável ao grupo HP-, porém, sem significância estatística. Já quanto à úlcera bulbar ( $\mathrm{HP}+=10,16 \%$ e HP- $=4,48 \%$ ), houve significância estatística $(p=0,00001)$. Conclusão: Não há diferenciação entre os grupos HP+ e HP- nas alterações endoscópicas inflamatórias na mucosa gastroduodenal, exceto para a relação entre HP e úlcera bulbar.

\section{INTRODUCTION}

T he discovery of Helicobacter pylori (HP) and the analysis of its correlation with inflammatory changes of the digestive mucosa has been the subject of numerous studies. Many points correlate this bacterium and wide range of gastroduodenal diseases by modifying the understanding of the pathophysiology and creating open questions whether its treatment can prevent complications.

It is known that the acquisition of this infection has interpersonal transmission, is related to socioeconomic and environmental factors, being more prevalent in developing countries ${ }^{4,18,26}$.

$\mathrm{HP}$ is gram-negative spiral bacillus, flagellate, usually not invasive, remaining on the surface of the gastric mucosa. Small proportion of the bacterial cells adheres to mucosal epithelium. Its spiral shape and flagella make it mobile on the mucosal environment 
and its effective urease protects against acid, catalyzing urea hydrolysis to produce ammonia buffer ${ }^{7}$.

HP infection is related to the development of lesions and gastric lymphomas; however, it is not known for sure if there is a correlation with gastroesophageal reflux and reflux esophagitis ${ }^{3,20}$. The literature already described its association with duodenitis ${ }^{6-8}$ and functional dyspepsia ${ }^{5,8-13}$.

Establish properly the relationship with the various gastroduodenal diseases is challenging, because the presence of infection has an influence in the same patient positively in some aspects and negative in others.

The aim of this study was to correlate the inflammatory endoscopic findings in positive and negative HP groups in order to examine whether there is a relationship with the onset of major mucosal diseases of the upper digestive tract.

\section{METHODS}

It is a comparative observational study. Data were collected from 2247 patients undergoing endoscopy and biopsies for HP with urease test attended by the Endoscopy Service, Hospital 9 of July, São Paulo, SP, Brazil.

Inclusion criteria were patients over 18 years of both genders who underwent endoscopy with rapid urease test, regardless of the examination reason request, ongoing disease or drug use. Exclusion criteria were: active bleeding during the examination; use of anticoagulants; without HP result by urease; HIV positive; with previous operations; tumors in the esophagus, stomach and duodenum; and when full and detailed examination was not possible (resistant to sedation, hypoxia or arrhythmia during the examination).

Based on 2247 patients was formed two groups: HP+ 16.6\% and HP- with $83.4 \%$. Within them, were searched endoscopic findings for the following alterations: esophagitis according to the Los Angeles classification, esophageal ulcer, non-erosive gastritis according to the Sydney classification, erosive gastritis, gastric ulcer, bulboduodenitis, bulbar ulcer and without disease. To identify ulcers, was used the definition of Paris classification.

For the urease and/or histological exams, biopsies were performed on body and antrum with biopsy forceps, and the material was placed in prefabricated reagent for the urease test.

The patients were previously submitted to the usual preparation for endoscopy - fasting for $8 \mathrm{~h}$ for solids and liquids. Immediately before the test were asked to ingest 10 $\mathrm{ml}$ of water with 40 drops of simethicone and, also, submitted to 5-10 puffs of lidocaine spray in the oropharynx.

\section{Statistical analysis}

For the analysis of the data was used the statistical software SPSS 23.0. Patients whose urease test was negative (HP-) served as control group for those who test was positive (HP+) in order that it could compare the HP presence influenced positively or negatively the studied conditions. To determine whether the samples had statistically significant results, was used the Pearson chi-square with an accuracy of $5 \%$ or $p<0.5$, in order to avoid results that could have been generated at random.

\section{RESULTS}

\section{Comparative analysis of mucosal changes}

\section{Esophagitis in $\mathrm{HP}+$ and $\mathrm{HP}$ - groups}

Comparing the incidence of esophagitis between $\mathrm{HP}+$ group (67.11\%) with the HP- control group (69.89\%) there was little disparity in the distribution favorable to $\mathrm{HP}+$ group that had slightly lower percentile of this disease. However, the data analysis about this disproportion was not statistically significant $(p=0.287464,>.05$, Table $1 \mathrm{~A})$
TABLE 1 - Incidence of esophagitis (A) and esophageal ulcer (B) in the HP+ and HP-groups

\begin{tabular}{|c|c|c|c|c|c|c|c|}
\hline \multirow{4}{*}{ A } & & $\begin{array}{c}\text { esophagitis } \\
\text { yes }\end{array}$ & $\%$ & $\begin{array}{c}\text { esophagitis } \\
\text { no }\end{array}$ & $\%$ & total & $\%$ \\
\hline & $\begin{array}{l}\text { Hpylori } \\
\text { positive }\end{array}$ & 251 & 67,11 & 123 & 32,89 & 374 & 100, \\
\hline & $\begin{array}{l}\text { Hpilory } \\
\text { negative }\end{array}$ & 1309 & 69,89 & 564 & 30,11 & 1873 & 100,00 \\
\hline & total & 1560 & 69,43 & 687 & 30,57 & 2247 & 100,0 \\
\hline \multirow{4}{*}{ B } & & $\begin{array}{c}\text { esopha ul } \\
\text { yes }\end{array}$ & $\%$ & $\begin{array}{c}\text { esopha ul } \\
\text { no }\end{array}$ & $\%$ & total & \\
\hline & $\begin{array}{l}\text { Hpylori } \\
\text { positive }\end{array}$ & 0 & 0,00 & 374 & 100 & 374 & 100,0 \\
\hline & $\begin{array}{l}\text { Hpilory } \\
\text { negative }\end{array}$ & 4 & 0,21 & 1869 & 99,79 & 1873 & $100,0 \mathrm{C}$ \\
\hline & total & 4 & 0,18 & 2243 & 99,82 & 2247 & 100 \\
\hline
\end{tabular}

Esophageal ulcer in $\mathrm{HP}+$ and $\mathrm{HP}$ - groups

Comparing the incidence of esophageal ulcer in $\mathrm{HP}+$ group (0\%) with the HP- $(0.21 \%)$ was observed low incidence in both groups, with small disproportion in favor distribution to HP+ group that showed no cases of this disease. However, analysis of the disproportion was not statistically significant $(p=0.371051,>.05$, Table 1B).

Gastritis in $\mathrm{HP}+$ and HP- groups

Comparing the incidence of gastritis in $\mathrm{HP}+$ group (78.34\%) with the HP- control group (73.63\%) there was a certain disproportion in the distribution, in favor of HP-group that had lower percentile. However, the data analysis of this disproportion was not statistically significant $(p=0.56,>.05$, Table 2).

TABLE 2 - Gastritis incidence on HP+ and HP- groups

\begin{tabular}{|c|c|c|c|c|c|c|}
\hline & $\begin{array}{c}\text { gastritis } \\
\text { yes }\end{array}$ & $\%$ & $\begin{array}{c}\text { gastritis } \\
\text { no }\end{array}$ & $\%$ & total & $\%$ \\
\hline $\begin{array}{l}\text { Hpylori } \\
\text { positive }\end{array}$ & 293 & 78,34 & 81 & 21,66 & 374 & 100,00 \\
\hline $\begin{array}{l}\text { Hpilory } \\
\text { negative }\end{array}$ & 1379 & 73,63 & 494 & 26,37 & 1873 & 100,00 \\
\hline total & 1672 & 74,41 & 575 & 25,59 & 2247 & 100,00 \\
\hline
\end{tabular}

Erosive gastritis in $\mathrm{HP}+$ and $\mathrm{HP}$ - groups

Comparing the incidence of erosive gastritis in $\mathrm{HP}+$ group (67.11\%) and HP- (64.55\%) there was little distribution disproportion in favor to the HP- group showing slightly lower percentile. However, the data analysis of this disproportion was not statistically significant $(p=0.343,>.05$, Table 3$)$.

TABLE 3 - Effect of erosive gastritis in $\mathrm{HP}+$ and HP- groups

\begin{tabular}{|c|c|c|c|c|c|c|} 
& $\begin{array}{c}\text { eros gast } \\
\text { yes }\end{array}$ & $\%$ & $\begin{array}{c}\text { eros gast } \\
\text { no }\end{array}$ & $\%$ & total & $\%$ \\
\hline $\begin{array}{c}\text { Hpylori } \\
\text { positive }\end{array}$ & 251 & 67,11 & 123 & 32,89 & 374 & 100,00 \\
$\begin{array}{c}\text { Hpilory } \\
\text { negative }\end{array}$ & 1209 & 64,55 & 664 & 35,45 & 1873 & 100,00 \\
\hline total & 1460 & 64,98 & 787 & 35,02 & 2247 & 100,00 \\
\hline
\end{tabular}

Bulboduodenitis in $\mathrm{HP}+$ and HP-groups

Comparing the incidence of bulboduodenitis in HP+ and HP-groups (1.23\%) was observed small disproportion in favor distribution to HP that showed slightly lower percentile group. However, the data analysis of this disproportion was not statistically significant $(p=0.322,>.05$, Table 4$)$. 
TABLE 4 - Bulboduodenitis incidence on HP+ and HP- groups

\begin{tabular}{|c|c|c|c|c|c|c|}
\hline & $\begin{array}{c}\text { bulboduo } \\
\text { yes }\end{array}$ & $\%$ & $\begin{array}{c}\text { bulboduo } \\
\text { no }\end{array}$ & $\%$ & total & $\%$ \\
\hline $\begin{array}{c}\text { Hpylori } \\
\text { positive }\end{array}$ & 7 & 1,87 & 367 & 98,13 & 374 & 100,00 \\
$\begin{array}{c}\text { Hpilory } \\
\text { negative }\end{array}$ & 23 & 1,23 & 1850 & 98,77 & 1873 & 100,00 \\
\hline total & 30 & 1,34 & 2217 & 98,66 & 2247 & 100,00 \\
\hline
\end{tabular}

Gastric ulcer in HP+ and HP- groups

Comparing the incidence of gastric ulcer in $\mathrm{HP}+$ group (2.14\%) and HP- (2.03\%) there was little disparity in the distribution, in favor to HP- group showing slightly lower percentile. However, the data analysis of this disproportion was not statistically significant $(p=0.523,>.05$, Table 5$)$.

TABLE 5 - Incidence of gastric ulcer in HP+ and HP- groups

\begin{tabular}{c|c|c|c|c|c|c|} 
& $\begin{array}{c}\text { gastr ul } \\
\text { yes }\end{array}$ & $\%$ & $\begin{array}{c}\text { gastr ul } \\
\text { no }\end{array}$ & $\%$ & total & $\%$ \\
\hline $\begin{array}{c}\text { Hpylori } \\
\text { positive }\end{array}$ & 8 & 2,14 & 366 & 97,86 & 374 & 100,00 \\
$\begin{array}{c}\text { Hpilory } \\
\text { negative }\end{array}$ & 38 & 2,03 & 1835 & 97,97 & 1873 & 100,00 \\
\hline total & 46 & 2,05 & 2201 & 97,95 & 2247 & 100,00 \\
\hline
\end{tabular}

Bulbar ulcer in HP+ and HP- groups

Comparing the incidence of bulbar ulcer in $\mathrm{HP}+$ group (10.16\%) with the HP-control group (4.48\%) was observed inequalities in the distribution, in favor of HP-group that had lower percentile. Furthermore, the analysis of data from this disproportion was highly statistically significant ( $p=0.00001$, $<.05$, Table 6A).

TABLE 6 - Incidence of bulbar ulcer (A) and absence of lesions (B) on HP+ and HP-groups

\begin{tabular}{|c|c|c|c|c|c|c|c|}
\hline \multirow{4}{*}{ A } & & $\begin{array}{c}\text { bulbar ul } \\
\text { yes }\end{array}$ & $\%$ & $\begin{array}{l}\text { bulbar ul } \\
\text { no }\end{array}$ & $\%$ & total & $\%$ \\
\hline & $\begin{array}{l}\text { Hpylori } \\
\text { positive }\end{array}$ & 38 & 10,16 & 336 & 89,84 & 374 & 100,00 \\
\hline & $\begin{array}{l}\text { Hpilory } \\
\text { negative }\end{array}$ & 84 & 4,48 & 1789 & 95,52 & 1873 & 100,00 \\
\hline & total & 122 & 5,46 & 2125 & 94,57 & 2247 & 100,00 \\
\hline \multirow{4}{*}{ B } & & $\begin{array}{c}\text { no alter } \\
\text { yes }\end{array}$ & $\%$ & $\begin{array}{c}\text { no alter } \\
\text { no }\end{array}$ & $\%$ & total & $\%$ \\
\hline & $\begin{array}{l}\text { Hpylori } \\
\text { positive }\end{array}$ & 18 & 4,81 & 356 & 95,19 & 374 & 100,00 \\
\hline & $\begin{array}{c}\text { Hpilory } \\
\text { negative }\end{array}$ & 118 & 6,30 & 1755 & 93,70 & 1873 & 100,00 \\
\hline & total & 136 & 6,05 & 2111 & 93,95 & 2247 & 100,00 \\
\hline
\end{tabular}

Absence of alterations in the HP+ and HP-groups

Comparing the incidence of the absence of changes in $\mathrm{HP}+$ group (4.81\%) with the HP- control group (6.30\%) there was a certain distribution disproportion in favor to the HPgroup that presented percentile a little larger than absence of disease. However, the data analysis of this disproportion was not statistically significant $(p=0.2708,>.05$, Table $6 B)$.

\section{DISCUSSION}

Colonization by HP mucosa predisposes to peptic ulcer disease, gastric atrophy and subsequent gastric cancer due to various changes in gastric acid secretion.

In this study the most common diseases for patients with $\mathrm{PH}+$ were gastritis (78.34\%), esophagitis (67.11\%) and erosive gastritis (67.11\%). Other diseases have very low prevalence and were bulbar ulcer (10.16\%), gastric ulcer (2.14\%), bulboduodenitis (1.87\%) and esophageal ulcer $(0.00 \%)$, with similar results already presented $3,5,17,23$.

Although the bacteria was initially implicated in the pathogenesis of gastroesophageal reflux and esophagitis, several studies have shown that its prevalence is smaller than the rest of population ${ }^{19,22,25,28}$. It is explained by gastric atrophy and subsequent reduction of gastric acid secretion, which would lead to lower esophageal injury. Nevertheless, due to its involvement in gastric carcinogenesis is recommended its erradication ${ }^{15,19}$.

It was not analyzed here the carcinogenic effects, direct or indirect, nor gastric atrophy or gastroesophageal reflux associated with infection by HP. It was possible to analyze data related to ulcers in the digestive tract, where it was confirmed a direct relationship between the presence of ulcers and $\mathrm{HP}+$; but only to bulbar ulcers this ratio proved to be significant. With no correlation with the literature, was observed the inverse relationship between HP and esophageal ulcer, but with very small and statistically insignificant disproportion.

The data also demonstrated an inverse relationship between the presence of HP and esophagitis, with smaller percentage for $\mathrm{HP}+$ group compared to HP-. The numbers of this relationship did not reach statistical significance, but confirmed the cited literature.

The HP infection is considered the main cause of chronic gastritis ${ }^{1,9}$ and studies suggest that this agent plays an important role in the genesis of peptic ulcer ${ }^{19}$. After finding that its eradication entails the healing of the ulcer, it was decided that patients with HP should receive specific treatment. The eradication of bacteria restores the gastric mucosa and end the carcinogenic development of acute gastritis (chronic gastritis - atrophy - metaplasia - dysplasia - cancer). Muller et. al. ${ }^{12}$ found that patients with HP+ showed odds ratio 10 times higher $(95 \% \mathrm{Cl}=6.50 \%-17 \%)$ to present some degrees of gastric mucosal injury than those with absence. It is estimated that only portion of infected individuals develop HP gastroduodenal diseases due to different pathogenic strains. Studies have shown that infection with HP- Cag A+ is associated with alterations in cell cycle and apoptosis in gastric epithelial and more pronounced levels of inflamation ${ }^{11,14}$. The HP Cag A+ is also associated with higher intensity of atrophy and intestinal metaplasia10,16,21,24.

Studies have also shown a strong relationship between duodenal ulcer and $\mathrm{HP}^{26,27}$. They found duodenal ulcer as the most common injury in their papers. Caetano et. al. ${ }^{2}$ studied 150 patients prospectively evaluating, from the total of 1,043 cases, chronic gastritis that was found in 109 patients (72.6\%), gastric ulcer in six (4\%), nine chronic duodenitis (6\%) and 26 duodenal ulcers (17.4\%). Then, they grouped patients in which 103 (68.67\%) had positive urease test, 104 (69.33\%) histologically positive and 98 (65.33\%) seropositivity for HP. Marques ${ }^{12}$, analyzing 1478 presented the most frequent endoscopic findings: gastritis $(n=810,54.8 \%)$; gastric and duodenal peptic ulcers $(n=494,33.4 \%)$; duodenitis $(n=287$, $19.4 \%)$ and esophagitis ( $n=217,14.7 \%)$; prevalence of HP infection in $53 \%(n=786)$ increasing the risk of gastric and duodenal ulcers in 1.9 and 1.6 times.

The data presented here had much lower percentage than reported in the literature (16.6\%). However, they denote certain propensity, although small and insignificant, of the $\mathrm{HP}+$ individuals to present changes in mucosal group, and on a global analysis, only $6.30 \%$ of HP+ group did not show any kind of change against $4.81 \%$ the HP- (control) group. It must be emphasized, again, that for specific relationship between HP and ulcer bulbar the numbers were significant. 


\section{CONCLUSION}

There is no differentiation between HP- and HP+ groups in endoscopic inflammatory changes in the gastroduodenal mucosa, except for the relationship between $\mathrm{HP}$ and bulbar ulcer.

\section{REFERENCES}

1. Ashorn M. What are the specific features of Helicobacter pylori gastritis in Children? Ann Med 1995; 27:617-20

2. Caetano A, Felix VN, Coimbra FTV, Ganc AJ. Helicobacterpylori e doença péptica. Estudocomparativo demétodosdiagnósticos.Arq.Gastroenterol 2008; 45(3):255-257

3. CremoniniF,DiCaroS,Delgado-ArosS,SepulvedaA, GasbarriniG, Gasbarrin A , et al. Meta-analysis: the relationship between Helicobacter pylor infection and gastrooesophageal reflux disease. Aliment PharmacolThe 2003; 18:279-289

4. DdineLC,DdineCC, RodriguesCCR, KirstenVR, ColpoE.Fatoresassociados com a gastrite crônica em pacientes com presença ou ausência do Helicobacterpylori. ArqBrasCirDig 2012;25(2):96-100

5. Ferreira LEVVC, Meirelles GSP, Vieira RLR, Bragagnolo Jr MA, Chebli JMF, Souza AFM. Alterações no teste ultra-rápido da uréase e no exame anatomopatológico para Helicobacterpylori induzidas por drogas antisecretoras. ArqGastroenterol. 2001; 38(1): 3-8

6. Genta RM, Kinsey RS, Singhal A, Suterwala S. Gastric foveolar metaplasia and gastric heterotopia in the duodenum: no evidence of an etiologic role for Helicobacter pylori. Hum Pathol. 2010; 41:1593-1600. 26

7. Go MF. Review article: natural history and epidemology of Helicobacter pylori infection. AlimentPharmacolTher. 2002; 16(suppl1):3-15

8. GuimaraesJ,CorveloTC,BarileKA. Helicobacterpylori:fatores relacionados a sua patogênese. Revista Paraense de Medicina. 2008; 22(1):33-38

9. Kawaguchi H, Haruma K, Komoto K, Yoshihara M, Sumii K, Kajiyama G. Helicobacter pylori infection is the major risk factor for atrophic gastritis. Am JGastroenterol1996; 51:959-62

10. Kidd M, Lastovica AJ, Atherton JC, Louw JA. Heterogeneity in the HelicobacterpylorivacAand cagAgenes:associationwith gastroduodenal disease in south Africa? Gut. 1999; 45:499-502

11. Kodaira MS, Escobar AMU, Grisi S. Aspectos epidemiológicos do Helicobacterpylori na infância e adolescência Rev Saúde Pública 2002 36(3):356-69

12. Marques, SB.Prevalência deinfecção pelo Helicobacterpyloriassociadaàs afecçõesdiagnosticadasporendoscopiadigestivaalta:análiseretrospectiva de 1478 casos. Dissertação de Mestrado - Faculdade de Medicina da Universidade de São Paulo. Departamento de Gastroenterologia, 2009
13. MirbagheriSS, MirbagheriSA, Nabavizadeh B, EntezariP, OstovanehMR, Hosseini SME, et al. Impact of Microscopic Duodenitis on Symptomatic Response to Helicobacter pylori Eradication in Functional Dyspepsia. Dig Dis Sci. 2015; 60:163-167

14. Moss SF, Sordillo EM, Abdalla AM, Makarov V, Hanzely Z, Perez-Perez GI, etal.Increased gastricepithelial cellapoptosisassociated withcolonization with CagA+ Helicobacter pylori strains. Cancer Res. 2001; 61:1406-11

15. Muller LB, FagundesRB, MoraesCC, Rampazzo A. Prevalência da infecção por Helicobacterpylori e das lesões precursoras do câncer gástrico em pacientes dispépticos. ArqGastroenterol. 2007; 44(2): 93-8

16. Nogueira C, Figueiredo C, Carneiro F, Gomes AT, Barreira R, Figueira P, etal.Helicobacterpylorigenotypesmay determinegastrichistopathology. Am J Pathol. 2001; 158:647-54

17. Nwokediuko SC, ljoma UN, Obienu O, Anigbo GE, Okafor O. High degree of duodenal inflammation in Nigerianswith functional dyspepsia. ClinExpGastroenterol. 2013; 7:7-12

18. Ratin ACF, ORSO IRB. Minimal endoscopic changes in non-erosive reflux disease. ArqBrasCirDig, 2015; 28(1): 20-23

19. RauwsEAJ, TytgatGNJ.Cure of duodenalulcerassociated witheradication of Helicobacter pylori.Lancet 1990; 335:1233-5

20. Rokkas T, Ladas SD, Triantafyllou K, Liatsos C, Petridou E, Papatheodorou G, Karameris A, Raptis SA: The association between CagA status and the development of esophagitis after the eradication of Helicobacter pylori. Am J Med 2001; 110:703-707

21. Sharma P, Vakil N. Review article: Helicobacter pylori and reflux disease. Aliment PharmacolTher. 2003; 17: 297-305

22. SuzukiH,MoayyediP.Helicobacterpylorïnfection infunctional dyspepsia. Nat Rev GastroenterolHepatol. 2013; 10:168-174

23. Take S, Mizuno M, Ishiki K, Nagahara Y, Yoshida T, Yokota K, Oguma K, Okada $\mathrm{H}$, Yamamoto K: Helicobacter pylori eradication may induce de novo, but transient and mild, reflux esophagitis: prospective endoscopic evaluation. J GastroenterolHepatol 2009; 24:107-113

24. Vaezi MF, Falk GW, Peek RM, Vicari JJ, Goldblum JR, Perez-Perez Gl et al. CagApositive strains of Helicobacter pylori may protect against Barrett's esophagus. Am J Gastroenterol. 2000; 95(9): 2206-2211

25. Vicari JJ, Peek RM, Falk GW, Goldblum JR, Easley KA, Schnell J. et al. The seroprevalence of cagApositiveHelicobacterpyloristrainsinthespectrum ofgastroesophageal reflux disease. Gastroenterology. 1998;115(1):50-57

26. Vomero ND, Colpo E. Nutritional care in peptic ulcer. Arq Bras Cir Dig, 2014; 27(4):298-302

27. Walker TD, Karemera M, Ngabonziza F, Kyamanywa P. Helicobacter pylori status and associated gastroscopic diagnoses in a tertiary hospital endoscopy population in Rwanda. Trans R Soc Trop Med Hyg 2014; 108:305-307

28. Werdmuller BF, Loffeld RJLF. Helicobacterpylori infection has no role in the pathogenesis of reflux esophagitis. Dig Dis Sci. 1997; 42(1):103-105 